\title{
Jean Anouilh, Le Voyageur sans bagage
}

\section{Emanuele Kanceff}

\section{(2) OpenEdition}

\section{Journals}

\section{Edizione digitale}

URL: http://journals.openedition.org/studifrancesi/9672

DOI: $10.4000 /$ studifrancesi.9672

ISSN: 2421-5856

\section{Editore}

Rosenberg \& Sellier

\section{Edizione cartacea}

Data di pubblicazione: 1 décembre 2007

Paginazione: 696-697

ISSN: 0039-2944

\section{Notizia bibliografica digitale}

Emanuele Kanceff, «Jean Anouilh, Le Voyageur sans bagage», Studi Francesi [Online], 153 (LI | III) | 2007 , online dal 30 novembre 2015, consultato il 12 janvier 2021. URL: http://journals.openedition.org/ studifrancesi/9672 ; DOI: https://doi.org/10.4000/studifrancesi.9672

\section{Questo documento è stato generato automaticamente il 12 janvier 2021.}

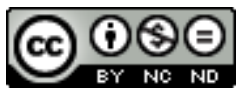

Studi Francesi è distribuita con Licenza Creative Commons Attribuzione - Non commerciale - Non opere derivate 4.0 Internazionale. 


\title{
Jean Anouilh, Le Voyageur sans bagage
}

\author{
Emanuele Kanceff
}

\section{NOTIZIA}

JEAN ANOUILH, Le Voyageur sans bagage, Édition présentée, établie et annotée par Bernard BEUGNOT, Paris, Gallimard, 2007, pp. 217 (Coll. «Folio Théâtre», 105).

1 Si tratta apparentemente solo di una riedizione della celebre opera di Anouilh pubblicata nel 1958. Ma si tratta di un'opera importante nella parabola teatrale dello scrittore, che fruisce in questo caso di una introduzione senza dubbio capitale, erudita e ben documentata ma anche fine nell'analisi del ruolo e del significato di questa pièce.

2 E non basta, perché l'edizione del testo, puntuale e scrupolosa, è seguita da un fitto «Dossier», che non è solo informazione del lettore, ma acuta indagine critica in cui tutti gli aspetti fondamentali sono passati in rassegna, dalle rappresentazioni alla genesi del testo alle fonti alla ricezione alle edizioni, e non mancano note essenziali, discretamente poste al fondo del libro. 